Vule Mizdraković ${ }^{1}$

Marija Kostić ${ }^{2}$

Jelena Stanković ${ }^{3}$
JEL: 123 and Q57

DOI: 10.5937/industrija46-19529

UDC: $378.14:[502.7: 33(497.11)$

Original Scientific Paper

\title{
Succeeding in Bioeconomy: Serbian Universities' Blueprint
}

\author{
Article history: \\ Received: 14 November 2018 \\ Sent for revision: 15 November 2018 \\ Received in revised form: 30 November 2018 \\ Accepted: 30 November 2018 \\ Available online: 28 Dec. 182018
}

\begin{abstract}
The purpose of this paper is to provide insight into the level of integration of the bioeconomy concept in the study programmes and modules at Serbian higher education institutions. Bioeconomy is based on multidisciplinary approach, which consists of research, education and innovation. Bioeconomy must be initiated by the government, developed by research institutions, universities and cluster, and thoroughly implemented into existing and emerging industries. As educators, Serbian universities should play a key role in developing future professionals. Research has been conducted to determine if Serbian universities educate students in the fields relevant to the concept of bioeconomy. All accredited study programmes in academic year of 2017/2018, at all universities in the Republic of Serbia, have been analysed. The research included 17 universities, 152 departments, 481 study programmes, 705 modules and 43,360 courses. The modules within the study programmes were categorised as bioeconomy-based modules, nonbioeconomy-based modules with at least one bioeconomy-based course, and non-bioeconomy-based modules. The research shows that of the total number of modules, $43 \%$ include one or more bioeconomy-based courses. The share of such courses within modules ranges from $1 \%$ to $21 \%$ and differs among groups of scientific fields.
\end{abstract}

Keywords: bioeconomy, university curricula, departments, bioeconomybased courses and modules, study programmes.

\footnotetext{
${ }^{1}$ Singidunum University, Belgrade, Republic of Serbia, vmizdrakovic@singidunum.ac.rs

${ }^{2}$ Singidunum University, Belgrade, Republic of Serbia

${ }^{3}$ Singidunum University, Belgrade, Republic of Serbia 


\section{Uspeti u bioekonomiji - trenutni prikaz univerziteta u Srbiji}

Apstrakt: Cilj ovog rada je da pruži uvid u nivo integracije koncepta bioekonomije u studijskim programima i modulima na univerzitetima u Republici Srbiji. Bioekonomija se zasniva na multidisciplinarnom pristupu, koji se sastoji od istraživanja, obrazovanja $i$ inovacija. Proces uvođenja bioekonomije mora biti iniciran od strane Vlade države, koja dalje podstiče razvoj istraživačkih institucija, univerziteta i klastera, a potom ih integriše u postojeće i nove industrijske delatnosti. Stoga, srpski univerziteti treba da imaju ključnu ulogu u razvoju budućih stručnjaka. Istraživanje je sprovedeno kako bi se utvrdilo da li srpski univerziteti obrazuju studente na poljima relevantnim za koncept bioekonomije. Analizirani su svi akreditovani studijski programi u akademskoj 2017/2018. godini, na svim univerzitetima u Republici Srbiji. Istraživanjem je obuhvaćeno 17 univerziteta, 152 fakulteta, 481 studijski program, 705 modula i 43.360 predmeta. Moduli u okviru studijskih programa kategorisani su kao: studijski moduli posvećeni bioekonomiji, moduli koji nisu posvećeni bioekonomiji sa najmanje jednim predmetom iz oblasti bioekonomije i moduli koji u celosti nisu posvećeni bioekonomiji. Istraživanje pokazuje da od ukupnog broja studijskih modula $43 \%$ uključuje jedan ili više predmeta posvećenih bioekonomiji. Učešće takvih predmeta u okviru modula kreće se od $1 \%$ do $21 \%$ i varira u zavisnosti od naučne oblasti.

Ključne reči: bioekonomija, kurikulumi studijskih programa, fakulteti, moduli i predmeti posvećeni bioeknomiji, studijski programi.

\section{Introduction}

Bioeconomy has become widely spread as an idea and as a concept of sustainable environmental, economic and social development. It can support overcoming barriers to the uptake of eco-friendly ways of life that is based upon an evolutionary complex systems approach to the choices that people make (Earl, 2017). Some authors (Papadopoulou, et al., 2018) go even further stating that bioeconomy will probably mark this century. Numerous challenges, such as food scarcity and insecurity, lack of preservation of natural resources and severe climate changes caused the emergence of the concept of bioeconomics. A bioeconomy can be defined as an economy in which production is based on renewable biological resources (McCormick \& Kautto, 2013), and how to use bioresources more sustainably than they are being used now (Muizniece, LeideTimma, Blumberga \& Blumberga, 2016); (Venkata Mohan, et al., 2016); (Zilberman, et al., 2018). Moreover, it is focused on the production of renewable biological resources and their conversion into food, feed, bio-based products and bioenergy (Haarich, 2017). The bioeconomy has an annual turnover of about 2 trillion euros and employs 
more than 22 million people, which is approximately $9 \%$ of the total European Union (EU) workforce (Socaciu, 2014). The bioeconomy requires permanent and extensive research and innovation in terms of technologies and processes, as well as the development of the market and the competitiveness of the bioeconomy sector. Bioeconomy will have an impact on modes and agendas in education, training and research (Koukios, et al., 2018); (Kangas, Tikkanen, Leskinen, Kurttila \& Kajanus, 2016). As providers of the necessary education and research, universities play a critical role in the development of the entrepreneurship culture. Essentially, their role is to accumulate and disseminate innovation and knowledge, thus strengthening the connection between research, invention and innovation (Vukićević \& Milošević, 2012), (Cvjetković, 2015). Therefore, higher education and the role of the universities have taken on profound significance. The concept of the bioeconomy derived from biotechnology. According to Saardchom (2017), it covers "all economic activities derived from the commercial application of biotechnologies to healthcare, industrial, agriculture sectors, and associated service areas that develop, produce, process, handle, or utilize any form of biological resources...". During previous decades, biotechnologies have been developed for environmentally sustainable production and various innovative products, primarily those made of biomaterials. There are several possible strategies for bioeconomy introduction and development in different countries and their economies. The incentive can come from entrepreneurs and business entities, higher education and research institutions, or alliances among any of these. The main purpose of this paper will be to underline the mission of universities as crucial educational and research institutions that should contribute strongly to the development of the bioeconomy and shape professionals in relevant areas. The main research question is thus, do universities in Serbia educate students, e.g. future professionals, in the fields relevant to the concept of bioeconomy? Subsequently, the research will explore the extent to which the bioeconomy is integrated into the following scientific fields in Serbian universities: natural and mathematical sciences, technical and technological sciences, social sciences, medical sciences and arts. The first part focuses on higher education and universities as the base for creation of the intellectual capital that ultimately helps develop the bioeconomy. The second part of the paper explains the research methodology or materials and methods used for the research. The last part presents the research findings and final discussion on the conducted scientific research related to the role of Serbian universities in successful implementation of bioeconomy. 


\section{Role of Universities in Creation of Intellectual Capital}

A number of studies have been conducted to determine critical factors that enable bioeconomy innovation and value creation in economies that base their progress and competitive advantages on sustainable development strategies (Gogan, 2014); (lazzolino \& Laise, 2016). Numerous studies showed that intellectual capital and its appropriate measuring are fundamental prerequisites for creating sustainable development, in both economic and social respects (Gogan, 2014; Komnenić, Tomić \& Tomić, 2010), (Ignjatović, Cogoljević \& Milenković, 2018). Intellectual capital, as the collective knowledge of individuals in organizations or societies, represents some of the intangible value of a business and covers four areas (Chen, Zhu, \& Yuan Xie, 2004):

- Human capital, embodied in employees' competencies;

- Innovation capital, as the capacity of an organization to implement research and development in creating new products;

- Customer capital, as the value embedded in marketing channels and relationships; and

- Structural capital, as 'what remains in the company when employees go home for the night' (Roos, Roos, Dragonetti \& Edvinsson 1997).

Intellectual capital is considered as one of the key factors of economic development and growth. The role of knowledge-based concepts and new technologies in European countries, was distinguished as one of the main goals of EU strategies (Jednak \& Kragulj, 2010). For example, the knowledgebased bioeconomy has become important for the agricultural research and development agenda of the EU (Levidow, Birch \& Papaioannou, 2012).

The concept of intellectual capital became an exciting area of research in the 1990s (Chen, et al., 2004); (Petty \& Guthrie, 2000). It has rapidly spread its influence on both researchers and practitioners. The interest and priorities of academia and industry are aligned, when it comes to the bioeconomy education because of its potential to create more workplaces (Grzyb, Hartman \& Field, 2017). As such, intellectual capital has become an important field of research and education in higher education institutions and university study programmes (Basile, 2009). In business practice and economies in general, intellectual capital is defined as 'organized knowledge that can be used to produce wealth' (Stewart, 1997). Unlike Chen et al. (2004), there are other authors that point out to three elements of intellectual capital (Kaplan \& Norton, 2004); (Stewart, 1997); (Sveiby, 1997):

- External capital, i.e. customers, suppliers,

- Internal capital, i.e. management, processes, procedures; and

- Human capital, i.e. knowledge, learning, business concepts. 
If applied to higher education, external capital includes the university district, the wider community, parents and local businesses. Among others, internal capital includes curriculum development and renewal or reform process of study programmes, while human capital includes the educators' knowledge and the structure and processes of professional development (Basile, 2009). Such a reform in study programmes and educational structure has been introduced by promoting multidisciplinary activities in the areas of bioenergy and bioproducts at the University of Maryland East Shore (UMES) through the Bioenergy and the Bioproducts Educational Program (Mitra, Nagchaudhuri \& Rutzke 2013).

The STEAM curriculum, which connects science, technology, engineering, agriculture and mathematics, provides an interdisciplinary perspective with the goal to prepare students, as future professionals and leaders, to address problems related to the environment. The study of Belgium (Vlaamse, 2013) shows that to develop further the potentials of the bioeconomy, it is crucial to raise the potentials of new professionals, mainly by providing them with the requisite knowledge base and up-to-date technologies. Therefore, building professional capacities should be strongly based and supported by integrating bioeconomy sectors in different industries with new bioeconomy curricula and vocational training programmes at universities (European Commission, 2012).

The above bioeconomy strategy for Europe was developed in 2012 as the part of a strategy for the countries of the European Union. Its key elements are research, innovation, education, training, management and work with community. Numerous countries such as Sweden, Germany, Finland and Belgium already have developed their own bioeconomy strategies and are implementing them in the systems of education and training of their future professionals (Blumberga, et al., 2017). Concept of bioeconomy supports sustainable development, thus it has to have a central role in economic strategies and policy (Petrović, Snider, Ćirović \& Milenković, 2012); (Biobased Industries Consortium, 2018). It has been noted by Ray, Srivastava, Diawakar, Nair \& Ozdemir (2016) "the overall success of developing nations thus rests on building successful linkages of the education ecosystem with social innovation and bioeconomy". According to Dietz, Boerner, Foerester \& Braun (2018) and other authors (Ristić, Mirković-Isaeva \& Vasić, 2018) many countries around the world have adopted political strategies in order to support their bioeconomies in the framework of the global Sustainable Development Goals (SDGs).

In Serbia, the incentive for strategic acceptance and development of the concept of the bioeconomy comes from universities, not government. There is still no official draft or an initiative for adoption of bioeconomy strategy. Some Serbian higher education institutions and universities have already implemented study programmes and learning outcomes that greatly contribute 
to bioeconomy development. It is still unknown; however, to what extent the concept of the bioeconomy is integrated into the study programmes, modules and course curricula of Serbian universities.

\section{Research Methodology}

Research was conducted to provide a precise strategy blueprint of Serbian universities when it comes to the integration of the concept of the bioeconomy in study programmes and courses. To do so, a systematic review of study programmes and courses was required. The research method used in some of the previously conducted studies (Tranfield, Denyer \& Smart, 2003), was determined to be adequate and was adopted for this research purpose. Therefore, the systematic review of study programmes and courses was executed in three stages:

- First stage - Planning the research (definition of the research objective and research question were explained in Introduction of the paper);

- Second stage - Conducting the research (review of all stateaccredited study programmes in universities from the Republic of Serbia; research covered the entire population; the list of stateaccredited study programmes and universities was available on the internet site of the Ministry of Education, Science and Technological Development; the research focused on the bachelor level because at this level, students gain fundamental knowledge and skills, which in most cases profile their future employment and education; all study programmes and course curricula were collected manually and separately analysed);

- Third stage - Reporting and dissemination of research results (research results have been presented; since the research covered the whole population, complex econometric models were unnecessary for implementation; recommendations and suggestions for future research have been provided).

Accreditation documents and data on the nature of the study programmes and courses were found on the universities' web sites. According to the national Law on Higher Education, all accredited universities have to prepare documents regarding their accredited study programmes and make them publicly available. The collected data were reviewed thoroughly, and the curricula for all courses on accredited study programmes were analysed. Table 1 shows the number of universities, departments, study programmes, study modules and courses included in the research. 
Mizdraković V., et al: Succeeding in Bioeconomy: Serbian Universities' Blueprint

Table 1. Higher education institutions in Serbia

\begin{tabular}{|l|c|c|c|c|c|}
\hline Values & Universities & Departments & $\begin{array}{c}\text { Study } \\
\text { programmes }\end{array}$ & $\begin{array}{c}\text { Study } \\
\text { modules }\end{array}$ & Courses \\
\hline $\begin{array}{l}\text { Total } \\
\text { numbers }\end{array}$ & 17 & 152 & 481 & 705 & 43,360 \\
\hline Average & 8 & 8.94 & 3.32 & 4.86 & 299.03 \\
\hline Median & 1 & 8 & 2 & 3 & 130 \\
\hline
\end{tabular}

Source: Authors' data

Higher education in Serbia is established through universities where each university consists of one or several departments. Approximately $53 \%$ of all universities are privately owned, with the remaining universities owned by the state. With respect to the number of departments, however, the share of private ownership is much lower (approximately 38\%). Regardless of ownership, all departments are obliged to create study programmes, which are supposed to be accredited by the state. Each study programme offers education through one or more modules.

To answer the research question regarding whether the universities in Serbia educate students, e.g. future professionals, in fields relevant to the concept of bioeconomy, curricula for all modules within study programmes were analysed. Based on that, all modules were classified into three groups:

- I group, bioeconomy-based modules, includes modules that educate students on bioeconomy and predominately consists of bioeconomybased courses;

- II group, non-bioeconomy-based modules that include at least one bioeconomy-based course, are modules in which curricula do not indicate that the focus of studies will be on bioeconomy, yet include at least one bioeconomy-based course; and

- III group, non-bioeconomy-based modules, which includes modules that do not have any bioeconomy-based courses and curricula that do not refer to the concept of bioeconomy.

The courses were classified in two groups according to the structure of the syllabus: bioeconomy-based and non-bioeconomy-based. The national Law on Higher Education instructs that lectures within each course should occur 15 weeks per semester. Therefore, if the syllabus (number of weeks or lessons) for a specific course is predominantly oriented towards bioeconomy, such a course was considered bioeconomy-based. 
Mizdraković V., et al: Succeeding in Bioeconomy: Serbian Universities' Blueprint

\section{Research Results}

All the curricula for the total number of courses were analysed; the results are presented in this part of the paper. Table 2 shows the structure of the study programmes and their courses based on the provided criteria.

Table 2. Study programmes and courses focused on bioeconomy

\begin{tabular}{|c|c|c|c|c|c|}
\hline $\begin{array}{c}\text { Number of } \\
\text { I group } \\
\text { modules }\end{array}$ & $\begin{array}{c}\text { Number of } \\
\text { pioeconomy-based } \\
\text { courses within I } \\
\text { group modules }\end{array}$ & $\begin{array}{c}\text { Total number } \\
\text { of courses } \\
\text { within I group } \\
\text { modules }\end{array}$ & $\begin{array}{c}\text { Number } \\
\text { of II group } \\
\text { modules }\end{array}$ & $\begin{array}{c}\text { Number of } \\
\text { bioeconomy- } \\
\text { based courses } \\
\text { within II group } \\
\text { modules }\end{array}$ & $\begin{array}{c}\text { Total number } \\
\text { of courses } \\
\text { within II group } \\
\text { modules }\end{array}$ \\
\hline 41 & 525 & 2,042 & 264 & 547 & 41,318 \\
\hline
\end{tabular}

Source: Authors' data

Out of 705 modules, almost $6 \%(n=41)$ were bioeconomy-based. Within these modules, $26 \%$ of courses were bioeconomy-based. Students that study these modules are reasonably assumed to become highly skilled professionals in bioeconomy. The share of the II group of modules equals $37 \%$. Approximately $1 \%$ of all courses within this group of modules are bioeconomy-based. The remaining number of modules, belonging to the III group was 400 or approximately $57 \%$. These modules do not include any courses that educate students on the concept of bioeconomy, according to their syllabi. Based on the foregoing, the results show that less than half of all future professionals will be informed about bioeconomy and its fundamentals in general. On the other hand, about $6 \%$ of all students have the opportunity to acquire higher level of expertise in the field of bioeconomy.

The structure of courses' syllabi within the I group show that the courses are created to enable each subsequent course to contribute to the knowledge gained during the previous one. Therefore, the courses are complementary, which enables the creation of professional expertise in bioeconomy. Although bioeconomy predominantly belongs to the natural sciences, the benefits of its use extend to different scientific fields. This will be elaborated in further text.

The official classification of the Ministry of Education, Science and Technological Development in Serbia distinguishes following scientific fields: natural and mathematical, technical and technological, and medical sciences. Based on this classification, all departments in this research were connected to the appropriate scientific field. This was done to provide data on how many bioeconomy-based courses or modules belong to each of them. 
Out of the total number of university departments, $45 \%$ belong to the social sciences, while $42 \%$ belong to the natural and mathematical, technical and technological, and medical sciences. Fig. 1 shows the share of modules and courses focused on bioeconomy within particular scientific fields: natural and mathematical sciences, technical and technological sciences, social sciences, medical sciences and arts.

Figure 1. I group modules and courses per scientific field

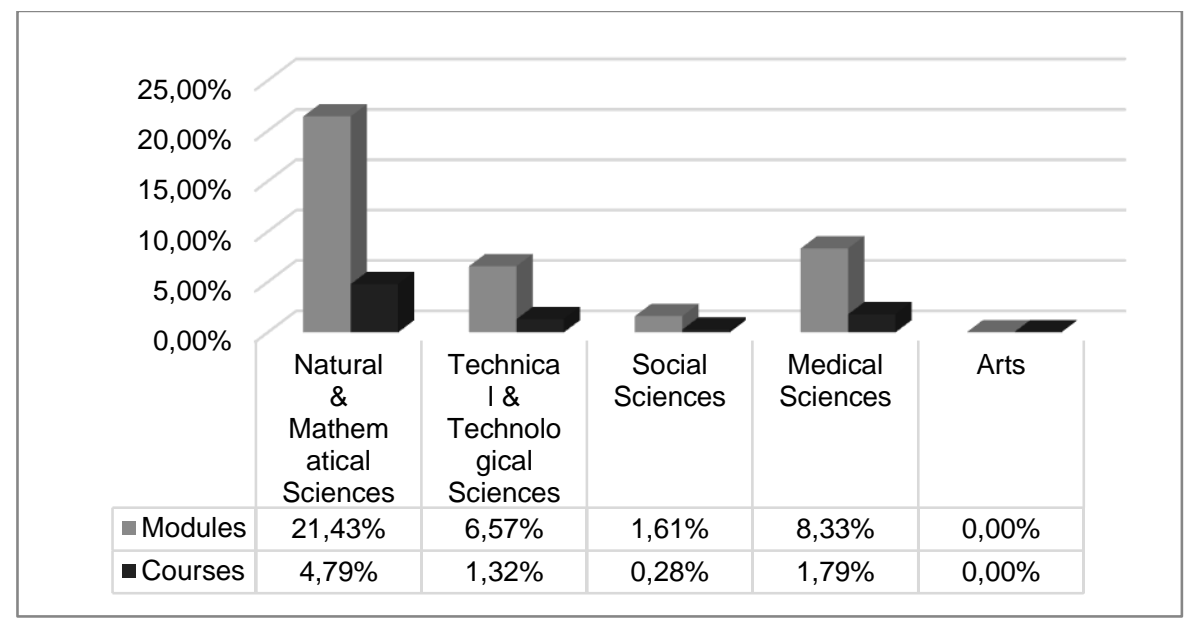

Source: Authors' data

The main focus of the research was to determine the number of bioeconomybased modules and courses in each particular department. According to the research results, departments within natural and mathematical, medical, and technical and technological scientific fields have the greatest share of modules and courses in bioeconomy. Thus, those three scientific fields contribute most to the introduction and development of the concept of bioeconomy in Serbia. That should result in the increase of research, innovation and entrepreneurship related to the bioeconomy. On the other hand, the share of bioeconomy-based modules and courses in the social science departments is significantly lower. It should be noted that the departments within social sciences comprise almost half of the total number of departments. The departments within natural and mathematical, technical \& technological and medical represent the other half.

This information reveals a challenge for all stakeholders in Serbia: it is necessary to increase the share of bioeconomy-based modules and courses in the social science departments, as soon as possible. This is suggested because contemporary management, businesses and society in general must 
be developed in accordance with the main principles of bioeconomy, and universities, as one of the stakeholders, should act as knowledge brokers (Lyytimaki et al., 2017). This research showed that departments focused on teaching and pedagogy have a particular bioeconomy course that introduces students to the basics of this concept. Other social sciences departments, especially those in the areas of economics and business sciences, should adopt this practice.

A good example of implementing bioeconomy in education is provided by the Faculty of Organizational Sciences, University of Belgrade. In the academic year of 2011/2012 Environmental management course at the third year of their undergraduate studies was introduced. The course included different topics in ecology, protection of natural resources, ecological management, and sustainable development (Petrović, et al., 2012).

Although particular departments have a certain share of bioeconomy-based modules, data show that the share of such courses is inadequate. Departments within the natural and mathematical scientific filed, for example, have less than $22 \%$ share of the modules. Out of the total number of courses on all modules within these departments, only $4.8 \%$ of them are bioeconomy based.

Figure 2. Non-bioeconomy-based modules with at least one bioeconomy based course per scientific field

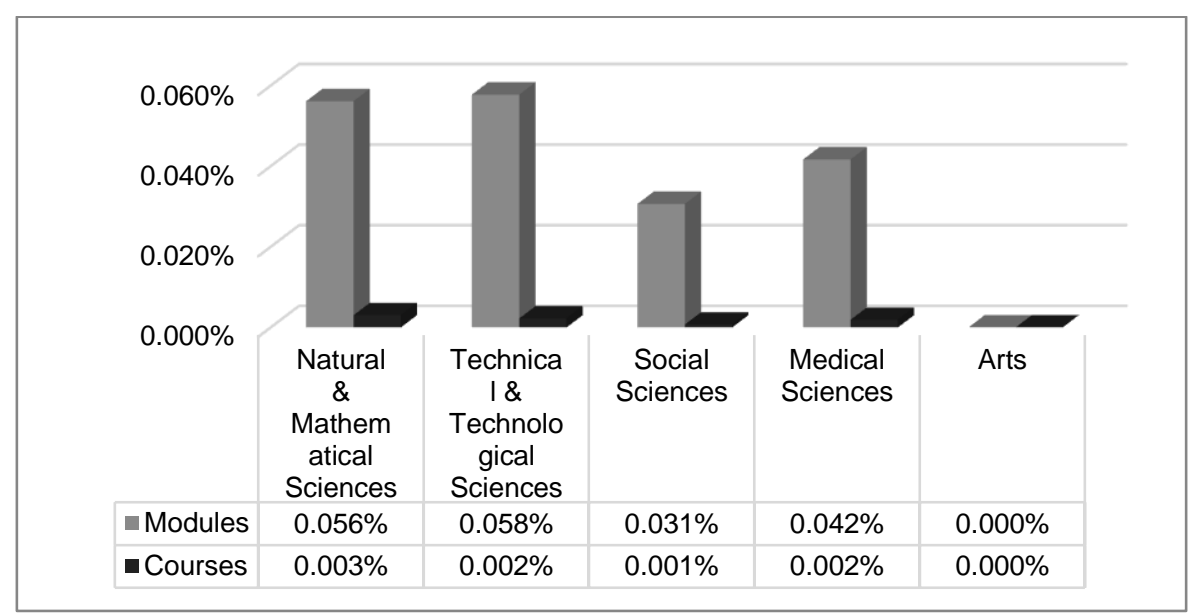

Source: Authors' data

When it comes to the second group of modules, Fig. 2 shows that this group represents more than a half of all modules within the natural and mathematical and technical and technological scientific fields. Within social 
and medical scientific fields, the share of non-bioeconomy-based modules is lower compared to the two previously mentioned.

On the other hand, the total share of bioeconomy-based courses within nonbioeconomy-based modules is as follows: less than $2 \%$ within the medical sciences; around 3\% within the natural and mathematical sciences; around $2 \%$ within the technical and technological sciences; and less than $1 \%$ within the social sciences. Based on the results, the general observation is that the share of bioeconomy-based courses within non-bioeconomy-based modules is again inadequate.

\section{Conclusion}

Starting with the initial research question, do the universities in Serbia educate students, e.g. future professionals, in the fields relevant to the concept of bioeconomy? this paper explored the extent to which bioeconomy is integrated in particular scientific fields and university departments in Serbia. Universities and higher education institutions, as the creators of intellectual capital, should contribute more to the development of bioeconomy in the Republic of Serbia. Serbian universities have started to incorporate bioeconomy-based modules and courses within their study programmes and curricula. The data show, however, that the share of those modules and courses remains low. Given that the concept of bioeconomy is an important part of European and global policy trends, its implementation and promotion through education, research and innovation will improve the domestic economy and business growth. Development of higher education and research competence, as well as institutional frameworks and market regulations, are essential for continued progress towards a more resourceefficient, circular bioeconomy. Initiating an ongoing transdisciplinary dialogue between universities, industry, government and civil society could help increase mutual understanding and identify new ways for long-term development of the bioeconomy that would produce essential societal benefits. In order to achieve this, the Serbian government should follow established practices of other developed countries. As an initial step, it should adopt a bioeconomy strategy to ensure the strengthening of bio-based industries and sustainable development in general. Regarding future research in this field, exploring the potential of bioeconomy-based competences in the labour market of Serbia is recommended. The employment rate of graduated students from bioeconomy-based and non-bioeconomy-based groups should be analysed and compared. The purpose of the analysis would be to understand the connection between universities and study programmes and the needs of industry and business. The results will show the extent to which education responds to the requirements of the economy in general. 
Mizdraković V., et al: Succeeding in Bioeconomy: Serbian Universities' Blueprint

\section{References}

Basile, C. (2009). Intellectual capital and professional development schools. Albany: SUNY Press.

Biobased Industries Consortium (2018). Bioeconomy and the UN Sustainable Development Goals. Retrieved from: https://biconsortium.eu/sites/biconsortium.eu/files/documents/Bioeconomy_and_t he_SDGs_July\%202018.pdf

Blumberga, D. et al, (2017). Why bioeconomy is actual for Latvia. Research achievements in Institute of Energy Systems and Environment. Energy Procedia, 113(1), 460-65. DOI: 10.1016/j.egypro.2017.04.039

Chen, J., Zhu, Z. \& Yuan Xie, H. (2004). Measuring intellectual capital: a new model and empirical study. Journal of Intellectual Capital, 5(1), 195-212. DOI: $10.1108 / 14691930410513003$

Cvjetković, M. (2015) Knowledge and quality as the factors of the business operations and competitiveness promotion - research results from Serbia. Industrija, 43(2), pp. 53-72.

Dietz, T., Boerner, J., Foerester, J. \& Braun, J. (2018) Governance of the Bioeconomy: A Global Comparative Study of National Bioeconomy Strategies. Sustainability, 10(9), 1-20. DOI: ssrn.com/abstract=3214439

Earl, P. (2017) Lifestyle changes and the lifestyle selection process. Journal of Bioeconomics, 19(1), 97-114. DOI: https://doi.org/10.1007/s10818-016-9212-0

European Commission, (2012). The bioeconomy strategy. Retrieved from: http://ec.europa.eu/research/bioeconomy/pdf/official-strategy en.pdf

Gogan, M. (2014). An innovative model for measuring intellectual capital. ProcediaSocial and Behavioral Sciences, 124(1), 194-99. DOI: 10.1016/j.sbspro.2014.02.477

Grzyb, K., Hartman, B.D. \& Field, K.G. (2017). Comparing industry and academia priorities in bioenergy education: a Delphi study. International Journal of Sustainable Energy, 37(10), 956-969. DOI: 10.1080/14786451.2017.1402769

Haarich, S. (2017). Bioeconomy development in EU regions. Final report, research and innovation. European Commission.

lazzolino, G. \& Laise, D. (2016). Value creation and sustainability in knowledge-based strategies. Journal of Intellectual Capital, 17(3), 457-70. DOI: 10.1108/JIC-092015-0082

Ignjatijević, S., Cogoljević, M. \& Milenković, N. (2018) Economic Assessment of Significance of Education in the Development of a Knowledge-Based Economy. Industrija, 46(3), pp. 185-200.

Jednak, S. \& Kragulj, D. (2010). Ekonomija zasnovana na znanju - osnov ekonomskog rasta i razvoja. Menadžment: Časopis za teoriju i praksu menadžmenta, 15(57), 5-13. DOI: 10.1093/aepp/ppx051 
Mizdraković V., et al: Succeeding in Bioeconomy: Serbian Universities' Blueprint

Kangas, J., Tikkanen, J., Leskinen, P., Kurttila, M. \& Kajanus, M. (2016) Developing hybrid SWOT methodologies for choosing joint bioeconomy co-operation priorities by three Finnish universities. Biofuels, 8(4), 459-471. DOI: 10.1080/17597269.2016.1271625

Kaplan, R. \& Norton, D. (2004). Measuring the strategic readiness of intangible assets. Harvard Business Review, 82(2), 52-63.

Komnenić, B., Tomić, D. \& Tomić, G. (2010). Measuring efficiency of intellectual capital in agriculture sector of Vojvodina. Budapest: Agroinform Publishing House.

Koukios, E., et al. (2018) Targeting sustainable bioeconomy: A new development strategy for Southern European countries. The Manifesto of the European Mezzogiorno. Journal of Cleaner Production, 172(1), 3931-3941.

Levidow, L., Birch, K. \& Papaioannou, T. (2012) Divergent Paradigms of European Agro-Food Innovation: The Knowledge-Based Bio-Economy (KBBE) as an R\&D Agenda. Science, Technology \& Human Values, 38(1), 1-32.

Lyytimaki, J., et al. (2017) Developing key indicators of green growth. Sustainable Development, 26(1), 51-64. DOI: 10.1002/sd.1690

McCormick, K. \& Kautto, N. (2013). The bioeconomy in Europe: an overview. Sustainability, 5(1), 2589-608. DOI: 10.3390/su5062589

Mitra, M., Nagchaudhuri, A. \& Rutzke, C. (2013). Energizing the STEAM curricula with bioenergy and bioproducts, 120th ASEE Annual Conference and Exposition. Atlanta, Georgia, 23-26 June, 2013. Washington, DC.

Muizniece, I., LeideTimma, L., Blumberga, A. \& Blumberga, D. (2016). The methodology for assessment of bioeconomy efficiency. Energy Procedia, 95(1), 482-86. DOI: 10.1016/j.egypro.2016.09.072

Papadopoulou, E., et al. (2018) Bio-Economy in Greece: Current Trends and the Road Ahead. The EuroBiotech Journal, 2(3), 137-145. DOI: 10.2478/ebtj-2018-0018

Petrović, N., Snider, A., Ćirović, M. \& Milenković, N. (2012). Debata u obrazovanju za održivi razvoj. Menadžment: Časopis za teoriju i praksu menadžmenta, 65(1), 3339. DOI: 10.7595/management.fon.2012.0031

Petty, R. \& Guthrie, J. (2000). Intellectual capital literature review: measurement, reporting and management. Journal of Intellectual Capital, 1(2), 155-76. DOI: 10.1108/14691930010348731

Ray, S., Srivastava, S., Diawakar, S., Nair, B. \& Ozdemir, V. (2016) Delivering on the Promise of Bioeconomy in the Developing World: Link It with Social Innovation and Education. In: Srivastava S. (eds) Biomarker Discovery in the Developing World: Dissecting the Pipeline for Meeting the Challenges. Springer, New Delhi, 77-81.

Ristić, V., Mirković-Isaeva, O. \& Vasić, B. (2018) Management of natural wealth resources curse and socio-economic development. Industrija, 46(2), pp. 131-150.

Roos, J., Roos, G., Dragonetti, N. \& Edvinsson, L. (1997). Intellectual capital. New York: Macmillan Business. 
Mizdraković V., et al: Succeeding in Bioeconomy: Serbian Universities' Blueprint

Saardchom, N. (2017). Bioeconomy as a New S-curve for Thai Economy. Agricultural Economics, 9(1), 430-439. DOI: 10.17221/78/2016-AGRICECON

Socaciu, C. (2014). Bioeconomy and green economy: European Strategies, action plans and impact of life quality. Bulletin UASVM Food Science and Technology, 71(1), 1-10. DOI: 10.15835/buasvmcn-fst:10121

Stewart, T. (1997). Intellectual capital. New York: Doubleday.

Sveiby, K. (1997). The new organizational wealth: managing and measuring knowledge-based assets. San Francisco: Barret-Kohler.

Tranfield, D., Denyer, D. \& Smart, P. (2003). Towards a Methodology for Developing Evidence-Informed Management Knowledge by Means of Systematic Review. British Journal of Management, 14(1), 207-222. DOI: 10.1111/1467-8551.00375

Venkata Mohan, S., Nikhil, G.N., Chiranjeevi, P., Nagendranatha Reddy, C., Rohit, M.V., Naresh Kumar, A. \& Omprakash Sarkar (2016) Waste biorefinery models towards sustainable circular bioeconomy: Critical review and future perspectives. Bioresource Technology, 215(1), 2-12. DOI: 10.1016/j.biortech.2016.03.130

Vlaamse, O. (2013). Bioeconomy in Flanders: The vision and strategy of the government of Flanders for sustainable and competititve bioeconomy in 2030. Retrieved from: http://ceebiofiles.testurl.be/content/files/2014-strategiebio economie en.pdf.

Vukicević, S. \& Milošević, S. (2012). IT, inovacije i održivost. Menadžment: Časopis za teoriju $i$ praksu menadžmenta, 65(1), 79-84. DOI: 10.7595/management.fon.2012.0029

Zilberman, D., Gordon, B., Hochman, G. \& Wesseler J. (2018). Economics of Sustainable Development and the Bioeconomy. Applied Economic Perspectives and Policy, 40(1), 22-37. DOI: 10.1093/aepp/ppx051 